Pometun, O., Hupan, N. (2019). Taksonomiia B. Bluma i rozvytok krytychnoho myslennia shkoliariv na urokakh istorii [B. Bloom's taxonomy and the development of pupils' critical thinking in history lessons]. Ukrainskyi pedahohichnyi zhurnal. №. 3. S. 50 58. [in Ukrainian].

Bondarenko, N. (2009). Tekstotsentrychna systema vyvchennia derzhavnoi movy: teoretychni i praktychni aspekty [Text-centric system of studying the state language: theoretical and practical aspects]. Derzhavotvorcha y obiednuvalna funktsii ukrainskoi movy: realii, zdobutky, perspektyvy. Uzhhorod: Lira. S. 143-153. [in Ukrainian].

Bondarenko, N. V. (2008). Robota z tekstom na urokakh ukrainskoi movy [Work with text in Ukrainian language lessons]. «Bibliotechka «Dyvoslova». № $5.56 \mathrm{~s}$. [in Ukrainian].

Bondarenko, N. V., Kosianchuk, S. V. (2017). Dydaktyko-metodychni zasady suchasnoho uroku ukrainskoi movy u starshii shkoli [Didactic and methodical principles of a modern Ukrainian language lesson in upper secondary school]. Humanitarnyi visnyk Poltavskoho natsionalnoho tekhnichnoho universytetu imeni Yuriia Kondratiuka. Vyp. 1. S. 81-89. [in Ukrainian].

Kosianchuk, S. V. (2014). Formuvannia tsinnisnosmyslovykh oriientatsii starshoklasnykiv v umovakh osobystisno-oriientovanoho navchannia [Formation of value-semantic orientations of upper secondary school pupils in the conditions of personality-oriented learning]. Onovlennia zmistu, form ta metodiv navchannia $i$ vykhovannia $v$ zakladakh osvity. Rivne: RDHU. Vyp. 8 (51). S. 132-136. [in Ukrainian].

Kosianchuk, S. V. (2018). Sotsializatsiia ta samovyznachennia osobystosti: apgreidery protsesu realizatsii pedahohichnykh tekhnolohii v umovakh profilnoho navchannia [Socialization and self-determination of personality: upgraders of the process of realization of pedagogical technologies in the conditions of profile education]. Psykholohiia svidomosti: teoriia i praktyka naukovykh doslidzhen. Kyiv: Talkom. S. 138-141. [in Ukrainian].

Kosianchuk, S. V. (2010). Chy spravdi rytoryka tak potribna starshoklasnykam? [Do high school pupils really need rhetoric?]. Vyvchaiemo ukrainsku movu i literature. № 34. S. 7-14. [in Ukrainian].

Rusalkina, L. M., Kosianchuk, S. V. (2009). Zasoby rytoryky yak osnova osobystisnoho zrostannia uchniv [Means of rhetoric as the basis of personal growth of pupils]. Ukrainska mova i literatura $v$ shkoli. № 8. S. 28-31. [in Ukrainian].

Дата надходження до редакиіï: 01.12. 2020 р.

В'ячеслав ДОЛІД, кандидат історичних наук, дочент, проректор із науково-педагогічної та навчальної роботи

Рівненського обласного інституту післядипломної педагогічної освіти, м. Рівне, Україна

ORCID: 0000-0002-8445-5410

e-mail:v.v.dolid@gmail.com

\section{Оксана ЛЮТКО,}

кандидат філософських наук, доиент, завідувач кафедри філософії, економіки та менеджменту освіти

Рівненського обласного інституту післядипломної педагогічної освіти, м. Рівне, Україна

ORCID: 0000-0003-2853-500X

e-mail: oksanaliutko@gmail.com

\title{
ОСОБЛИВОСТІ ОЦІНЮВАННЯ ДІЯЛЬНОСТІ ПЕДАГОГІЧНИХ ПРАЦІВНИКІВ ЗАКЛАДІВ ДОШКІЛЬНОӦ ОСВІТИ В КОНТЕКСТІ ІНСТИТУЦІЙНОГО АУДИТУ
}

\begin{abstract}
Анотація. У статті наголошується на пріоритетності забезпечення якості освіти в проиесі реалізаиії державної освітньої політики. Зазначається, що підвищення якості освітніх послуг $i$ забезпечення довіри до результатів навчання можливе передусім за рахунок розбудови внутрішньої системи забезпечення якості освіти. Відповідно до иього проаналізовано наказ МОН України «Про затвердження Порядку проведен-
\end{abstract}

ня інституиійного аудиту закладів загальної середньої освіти» (2019), в додатку до якого встановлено низку вимог до освітніх і управлінських процесів, а також посібник для керівників закладів загальної середньої освіти «Абетка для директора», підготовленого, фахівиями Державної служби якості освіти України, де вміщено рекомендації щодо розбудови внутрішньої системи забезпечення якості освіти. Наголошується, щчо для закладів дошкільної освіти 
розроблено лише Методичні рекомендаиії щзодо розбудови внутрішньої системи забезпечення якості освіти, в додатках до яких представлено вимоги до освітніх і управлінських процесів.
Ключові слова: якість освіти, якість освітньої діяльності, внутрішня система забезпечення якості освіти, оцінювання діяльності педагогічних працівників, заклад дошкільної освіти.

\section{EVALUATION FEATURES ACTIVITY OF PEDAGOGICAL WORKERS AT INSTITUTIONS OF PRESCHOOL EDUCATION IN THE CONTEXT OF INSTITUTIONAL AUDIT}

\begin{abstract}
Annotation. The article emphasizes that the quality of education and the quality of educational activities are fundamental principles of state educational policy. This means that the improvement of the work of any educational institution can be achieved primarily through continuous improvement of the quality of educational activities and involves targeted activities of managers in this direction, including the development of internal quality assurance system of education.

In January 2019, the procedure for conducting an institutional audit of general secondary education institutions was approved, in the appendix all requirements for educational and management processes are spelled out. In addition, the specialists of the State Quality Service of Education of Ukraine have prepared a manual for heads of general secondary education institutions "Alphabet for the principal» with recommendations for building an internal system of quality assurance in general secondary education. Only Methodical recommendations for the development of an internal system for ensuring the quality of education have been developed for preschool institutions, the appendices of which contain requirements for the activities of pedagogical staff of preschool institutions. In this regard, it is extremely important for the management and pedagogical staff of preschool education institutions to rethink their pedagogical and managerial experience and understand the components of effective planning and quality organization of the educational process. That is why our goal is to outline the key guidelines of professional activity of pedagogical staff of preschool education institutions, which are based on the analysis of requirements and criteria by which the activity of pedagogical staff will be evaluated during the institutional audit.
\end{abstract}

Key words: quality of education, quality of educational activity, internal system of quality assurance of education, evaluation of activity of pedagogical workers, preschool education institution.

Постановка проблеми. Законом України «Про освіту» передбачено створення в державі системи забезпечення якості освіти, невід'ємними складовими якої є: система забезпечення якості в закладах освіти, або внутрішня система забезпечення якості освіти; система зовнішнього забезпечення якості освіти; система забезпечення якості в діяльності органів управління та установ, що здійснюють зовнішнє забезпечення якості освіти. Найважливішою складовою для керівника закладу освіти $є$ внутрішня система забезпечення якості освіти - своєрідний інструмент, який допоможе розвивати заклад.

Відповідно до Закону України «Про освіту» функціонування внутрішньої системи забезпечення якості освіти забезпечує керівник закладу освіти (ст. 26), а за забезпечення якості освіти на відповідній території несуть відповідальність органи місцевого самоврядування (ст. 66). На виконання статті 67 означеного закону також утворено центральний орган виконавчої влади щодо забезпечення якості освіти - Державна служба якості освіти України (далі - ДСЯОУ), до повноважень якої належать питання допомоги керівникам і засновникам закладів освіти у формуванні внутрішньої системи забезпечення якості освіти, що має створити умови для постійного і послідовного вдосконалення якості освітніх і управлінських процесів. 
За розбудову внутрішньої системи забезпечення якості освіти відповідно до Закону України «Про повну загальну середню освіту» несе відповідальність керівник закладу освіти (ст. 38), а за проведення інституційного аудиту - ДСЯОУ та ії територіальні органи. Ці дві системи тісно пов'язані між собою, оскільки критерії, за якими буде проводитися щорічне самооцінювання освітньої діяльності закладу та критерії, які будуть використовуватися при інституційному аудиті, - однакові (Закон України «Про освіту», 2017).

Наказом Міністерства освіти і науки України було затверджено Порядок проведення інституційного аудиту закладів загальної середньої освіти (2019), в додатку до якого встановлено чіткі вимоги до організації освітніх і управлінських процесів закладу освіти та внутрішньої системи забезпечення якості освіти. Щодо закладів дошкільної освіти (далі - ЗДО), то існують лише Методичні рекомендації з питань формування внутрішньої системи забезпечення якості освіти у закладах дошкільної освіти (2020), в яких містяться критерії та індикатори для самооцінювання освітніх і управлінських процесів.

Аналіз наукових досліджень і публікацій. На сьогодні окреслені в статті проблеми не знайшли належного висвітлення в дослідженнях вітчизняних учених та науковців. Серед поодиноких праць, які частково можна віднести до змістовного контексту обраної нами теми, варто виокремити наукові розвідки Г. Дмитренка, Г. Єльникової, О. Пастовенського. Т. Сорочан.

Незначна кількість досліджень зі студійованої теми переконує в необхідності проведення досліджень у даному напрямі, на нашу думку, неабияк підвищить рівень іiі актуальності.

Мета статті - окреслення ключових орієнтирів фахової діяльності педагогічних працівників закладів дошкільної освіти на основі аналізу вимог та критеріїв, за якими оцінюватимуть діяльність педагогічних працівників під час інституційного аудиту.

Виклад основного матеріалу дослідження. Державна служба якості освіти України пропонує обрати чотири напрями для розбудови внутрішньої системи забезпечення якості освіти у ЗДО, а саме: освітнє середовище, здобувачі дошкільної освіти, фахова діяльність педагогічних працівників, управлінські процеси.

До фахової діяльності педагогічних працівників ЗДО висуваються чотири вимоги: 1) ефективне планування діяльності та якісна організація освітнього процесу; 2) постійне підвищення професійної майстерності педагогічних працівників; 3) налагодження співпраці з батьками, працівниками ЗДО; 4) методичне забезпечення ЗДО.

Периу вимогу - ефективне планування діяльності та якісна організація освітнього процесу - експерти інституційного аудиту оцінюватимуть за такими критеріями: планування педагогом своєї діяльності та аналіз iii результативності; застосування педагогом сучасних технологій та методик, спрямованих на формування ключових компетентностей і наскрізних умінь здобувачів дошкільної освіти; створення та використання педагогом освітніх ресурсів. Розглянемо означені критерії більш детально.

Відомо, що організацію освітнього процесу забезпечують педагоги. Вони складають перспективні та календарні плани, враховуючи Базовий компонент дошкільної освіти і програми розвитку дітей. Саме календарний план є основним робочим документом, який визначає діяльність педагогічного працівника та допомагає досягти очікуваних результатів освітньої роботи

Календарний план - це результат творчої роботи педагога, його бачення способів і напрямів отримання очікуваних результатів освітньої роботи. Основними принципами календарного планування $є$ : послідовність у викладенні матеріалу, чіткість поставлених завдань, відповідність форм роботи віковим та індивідуальним особливостям дітей, різноманітність видів діяльності тощо. Робота музичних керівників, інструкторів із фізичної культури, вихователів з образотворчої діяльності та інших педагогічних працівників планується окремо для кожної вікової групи. Такі плани узгоджуються з планами роботи вихователів.

Форм і видів планування є значна кількість. Окрім цього, існують рекомендації МОН щодо планування роботи в ЗДО (лист МОН України від 03.07.2009 p. № 1/9-455). Важливо, аби в кінці навчального року педагогічні працівники зробили аналіз реалізації планування та визначили напрями вирішення проблем, що виникали у ході використання календарного планування впродовж навчального року.

Наступний критерій - застосування педагогом сучасних технологій та методик в освітньому процесі, спрямованих на формування ключових компетентностей і наскрізних умінь здобувачів дошкільної освіти. У 2021 році Базовий компонент дошкільної освіти було оновлено з метою забезпечення єдності та наступності процесу реформування дошкільної та початкової освіти. У ньому зокрема зазначається, що компетентності формуються в дитини за 7 освітніми напрямами роботи ЗДО через організацію педагогом базових (основних) видів діяльності. Результати навчання сформовані шляхом визначення 13 компетентностей: рухової, здоров'язбережувальної, предметно-практичної, технологічної, природничо-екологічної, ігрової, соціально-громадянської, мовленнєвої, комунікативної, літературно-художньої, мистецької, особистісної та сенсорно-пізнавальної, логіко-математичної, дослідницької (наказ МОН України від 12.01.2021 р. № 33). В Інструктивно-методичних рекомендаціях «Щодо організації діяльності закладів дошкільної освіти у 2020/2021 навчальному році» (далі-Рекомендащіi) наголошується на пріоритетності формування комунікативно-мовленнєвої та математичної компетентностей, оскільки 2020/2021 навчальний рік оголошено Роком математики, та зазначається, що на сучасному етапі розвитку дошкільної освіти спостерігається тенденція до більш широкого використання комп'ютерних технологій для виховання, навчання та розвитку дітей дошкільного віку (Інструктивно-методичні рекомендації, 2020). Тобто наголошується на необхідності розвитку інформативної компетентності.

Зміст Базового компонента дошкільної освіти побудовано на основі чотирьох підходів: компетентнісного (спрямованість освітнього процесу на досягнення результатів, якими є сформовані компетентності); діяльнісного (спрямованість освітнього процесу на розвиток умінь і навичок особистості, застосування на практиці здобутих знань, успішну адаптацію дитини в соціумі, формування здібностей до колективної діяльності та самоосвіти); особистісно зорієнтованого (спрямованість освітнього процесу на взаємодію та 
плідний розвиток особистості педагога і дітей на основі рівності у спілкуванні та партнерства у навчанні); інтегрованого. У зв'язку з цим в Енциклопедії освіти інтегрований підхід в освіті схарактеризовано як «підхід, спрямований на інтеграцію змісту, тобто доцільного об'єднання його елементів у цілісність, і результатом застосування якого в педагогіці можуть бути цілісні знання різних рівнів: про дійсність; про природу; з тієі чи іншої освітньої лінії тощо» (Енциклопедія освіти, 2008 , c. 356).

Наступне поняття, яке міститься в критеріях, - це «наскрізні вміння». Як відомо, вміння - це готовність людини успішно виконувати певну діяльність, що грунтується на знаннях і навичках. У Законі України «Про освіту», Державному стандарті початкової освіти та Державному стандарті базової середньої освіти перераховано вміння, які $є$ спільними (наскрізними) для всіх компетентностей, і які педагоги повинні розвивати. До них віднесено вміння: висловлювати власну думку як усно, так і письмово; критичне та системне мислення; здатність логічно обгрунтовувати позицію; творчість; ініціативність; уміння конструктивно керувати емоціями; вміння оцінювати ризики, приймати рішення, розв'язувати проблеми; здатність співпрацювати з іншими людьми. У Базовому компоненті дошкільної освіти наскрізні вміння, на жаль, чітко не окреслені. Однак керівникам закладів освіти у своїй роботі можна орієнтуватися на дослідження професора А. Богуш. Ми солідарні з їі думкою стосовно того, що кінцевим результатом передшкільної освіти повинна бути сформована у дітей дошкільна зрілість.

Ученою було визначено компоненти і показники дошкільної зрілості, а саме:

1. Особистісно зорієнтований компонент із показниками:

- усвідомлення дитиною образу «Я», його місця в системі взаємовідносин;

- сформованість базових якостей особистості дошкільника: самосвідомість, самооцінка, самоставлення, самовпевненість, самостійність, ініціативність, креативність, відповідальність і свобода вибору.

2. Емоиійно-иіннісний компонент із показниками: емочійна усталеність дитини;

- позитивно-мотиваційна спрямованість на здобуття нових знань, умінь і навичок;

- установлення позитивних взаємовідносин у новому шкільному колективі;

- готовність до набуття нової соціальної позиції «Я учень», «Я школяр».

3. Операційно-діяльнісний компонент із показниками:

- сформованість знань, умінь і навичок, необхідних для навчання у школі;

- довільність психічних процесів і поведінки;

- наявність передумов навчальної діяльності (сформованість різних видів компетенцій за БКДО) (Богуш, 2015, с. 158-163).

Окрім того, в програмі «Впевнений старт» дається характеристика психологічної зрілості та показники засвоєння програми.

У Рекомендаціях пріоритетним напрямом у 2020/2021 навчальному році визначено «забезпечення наступності у впровадженні особистісно орієнтованої моделі освіти в дошкільній та початковій ланках освіти. Для реалізації вимог обох ланок освіти (орієнтуючись на Концепцію «Нова українська школа», іiї новий зміст, зміну освітнього простору) результативною $\epsilon$ така форма взаємодії, як педагогічне партнерство вихователів ЗДО та вчителів перших класів щодо створення розвивального середовища, осередків діяльності, застосування компетентнісного та діяльнісного підходів у ході освітнього процесу для розвитку особистості, організації та проведення ранкових зустрічей, використання ігрових методів під час навчальних занять» (Інструктивно-методичні рекомендації, 2020). 3 огляду на важливість наступності дошкільної та початкової освіти варто взяти до уваги перелік наскрізних умінь початкової освіти і розвивати їх, використовуючи, наприклад, методику «Шість цеглинок».

Технологій і методів навчання $є$ надзвичайно велика кількість. До технологій, які вже пройшли апробацію й успішно застосовуються педагогами, відносять інтерактивні, інформаційно-комунікативні та ігрові. У Рекомендаціях акцент зроблено на інформаційно-комунікаційній технології (далі - IKT) та формуванні соціально доцільної поведінки.

Вивчення й оцінювання використання педагогами IКТ під час інституційного аудиту може здійснюватись через спостереження за проведенням занять та за кількістю створених електронних ресурсів. Рівень оволодіння педагогами IКТ може враховуватись у процесі атестації педагогічних працівників, можливостей матеріального та морального заохочення.

Технологія формування соціально доцільної поведінки покликана допомогти дітям соціалізуватися. Оскільки технологія - це система педагогічних засобів, форм, методів для вирішення конкретного завдання, то гра залишається найефективнішим засобом соціалізації дошкільника, адже саме в грі дитина активно пізнає навколишній світ, стосунки між людьми, правила і норми поведінки, усвідомлює свої можливості, взаємозв'язки з іншими тощо.

Друга вимога - постійне підвищення професійного рівня і педагогічної майстерності педагогічних праиівників. Оцінювати означену вимогу експерти будуть за наступними критеріями: 1) забезпечення педагогічними працівниками власного професійного розвитку і підвищення кваліфікації з використанням різних видів, форм і напрямів, зокрема щодо методик роботи з дітьми з особливими освітніми потребами; 2) здійснення педагогічними працівниками інноваційної освітньої діяльності та участь в освітніх проєктах.

Необхідною умовою професійної діяльності педагогічного працівника та його зростання є самоосвіта. Підвищення кваліфікації, вдосконалення професійного розвитку - це не тільки курсова перепідготовка в закладі післядипломної педагогічної освіти. Це також участь педагогічних працівників у різноманітних тренінгах, конференціях, семінарах, вебінарах, онлайн-курсах тощо.

Форм підвищення кваліфікації сьогодні є велика кількість:

- колективні (лекторії, онлайн-курси, семінари, тренінги, конференції, платформи для професійного зростання тощо);

- групові (об'єднання вихователів за певними напрямами діяльності, творчі групи, ділові ігри, взаємовідвідування занять і рефлексія, перегляд та обговорення відеозаписів показових занять);

- індивідуальні (фасилітація, створенням мультимедійних презентацій, рефлексивний аналіз власних занять, самоосвіта, робота над індивідуальною творчою темою тощо). 
Процес професійного зростання педагога не обмежується лише формами підвищення кваліфікації за межами закладу. Це повинен бути безперервний системний процес: обмін досвідом, практика педагогічного наставництва, розроблення системи навчальних занять, публікації в друкованих та електронних виданнях, методичні розробки та самоосвіта тощо.

Під час вивчення внутрішньої системи забезпечення якості освіти ЗДО відбуватиметься аналіз процесу підвищення кваліфікації педагогічних працівників та зростання їхнього якісно-кваліфікаційного рівня, що може свідчити про вдосконалення освітньої діяльності у закладі освіти.

Наступний критерій - здійснення педагогічними працівниками інноваційної освітньої діяльності та участь в освітніх проєктах. Інновація - це процес освоєння засобу (нового методу, методики, технології, програми тощо); цілеспрямована зміна, що вносить в освітнє середовище нові стабільні елементи та викликає перехід системи $з$ одного стану в інший. Під інноваціями у навчанні розуміють нові методики викладання, нові способи організації занять, нововведення в організації змісту освіти (наприклад, інтеграційні програми) (Енциклопедія освіти, 2008, с. 338-340).

На сьогодні існує низка ефективних технологій програм, в яких здійснено модернізацію змісту та форм організації освітньої діяльності, зокрема:

- програма «Впевнений старт» із повним навчально-методичним супроводом для дитини, вихователя та батьків;

- технологія методичного конструктора на основі блочно-тематичного планування - реальне забезпечення принципу інтеграції як змісту освіти, так і діяльності дітей;

- програма «Дошкільнятам - освіта для сталого розвитку»;

- технологія складання інтелектуальних карт у плануванні та організації освітнього процесу на засадах інтеграції;

- програма STREAM-освіти;

- авторські, парціальні та багато інших.

третя вимога - налагодження співпраці з батьками, працівниками ЗДО - оцінюватиметься за такими критеріями: діяльність педагогічних працівників на засадах педагогіки партнерства; співпраця педагогів iз батьками з питань розвитку, навчання та виховання дітей, а також своєчасне забезпечення зворотного зв'язку; налагодженість у закладі практики педагогічного наставництва та інших форм професійної співпраці; налагодженість системи роботи з адаптації та інтеграції здобувачів дошкільної освіти до освітнього процесу.

Для підвищення ефективності освітнього процесу необхідний постійний діалог із батьками. Конструктивне партнерство, доброзичливі взаємини, наявність зворотного зв'язку щодо успіхів дитини, їі прогрес у навчанні, залучення батьків до життя групи і закладу $є$ запорукою якісного освітнього процесу. Головна мета змін - спілкування батьків із закладом освіти в контексті життя ЗДО, в якому навчається їхня дитини. Для цього потрібно змінювати форму проведення зустрічей із батьками та їхній зміст, аби була можливість поговорити - про дітей, групу, садочок, про свої батьківські проблеми. Форм роботи з батьками в ЗДО є багато. Умовно їх можна поділити на колективні, активні та індивідуальні.

При плануванні співпраці з батьками необхідно враховувати особливості родин: склад, вік батьків, їхню освіту та період перебування в шлюбі, кількість дітей, досвід батьківства, матеріальний стан, умови проживання, професійні інтереси, віросповідання, етнічну, соціальну та культурну приналежність сім'ї тощо.

Якщо говорити про критерій «налагодженість у закладі практики педагогічного наставництва та інших форм професійної співпраці», то варто зауважити, що команда залишається ключовим методом досягнення успіху більшості організацій у будь-якій сфері діяльності. Зважаючи на це, кожен сучасний лідер-управлінець має володіти методикою командотворення - діяльності, спрямованої на об'єднання і заохочення членів групи до спільної результативної діяльності.

Під час інституційного аудиту будуть використовуватися індикатори / показники, що відображають хід процесу або стан об'єкта спостереження, його якісні або кількісні характеристики. Зокрема будуть визначати: частку (\%) педагогів, які використовують форми роботи, спрямовані на формування партнерських взаємин iз батьками; чи налагоджена у закладі конструктивна комунікація педагогів із батьками в різних формах; чи надають педагогічні працівники методичну підтримку колегам, обмінюються досвідом; чи зорієнтовані педагогічні працівники на потреби дитини в освітньому процесі, проявляють повагу та доброзичливе ставлення до особистості дитини. Для оцінки означених процесів використовуватимуть різні методи збору інформації, зокрема анкетування батьків здобувачів дошкільної освіти та педагогічних працівників, інтерв'ю $з$ методистом і директором, спостереження за заняттям.

Четверта вимога - методичне забезпечення ЗДО - містить один критерій, а саме: «у ЗДО функціонує методичний кабінет». Важливо, щоб діяльність методичного кабінету була спрямована на: реалізацію стратегії розвитку та завдань ЗДО, підвищення якості освітнього процесу та професійної компетентності педагогічних працівників, забезпечення в закладі наступності дошкільної та початкової освіти, доступність інформаційно-просвітницького простору, сприяння відкритості та прозорості діяльності ЗДО.

Висновки. Виконання дій щодо розбудови внутрішньої системи забезпечення якості освіти - справа надзвичайно складна. Відсутність стратегічного та поточного планування освітньої діяльності, відсутність наявності необхідних ресурсів для організації освітнього процесу, небажання педагогів удосконалювати професійні компетентності негативно впливають на формування та підтримку культури якості освітньої діяльності. Усе це вимагає регулярного звернення до самоаналізу освітніх і управлінських процесів, відстеження якісних параметрів змін, а на кінець поточного року планування розвитку закладу на наступний навчальний рік.

Опираючись на вимоги до діяльності педагогічних працівників закладів дошкільної освіти нами було окреслено ключові орієнтири їх фахової діяльності, які дозволять як керівним, так і педагогічним працівникам підготуватися до майбутніх змін.

Перспективи подальших досліджень. Необхідність забезпечення якості освітньої діяльності та якості освіти ЗДО зумовлює потребу подальших досліджень. Серед перспективних напрямків варто виокремити вивчення основних підходів до оцінки діяльності закладу дошкільної освіти й аналіз їхньої ефективності, а також тенденції розвитку системи оцінювання результатів освітньої діяльності закладів дошкільної освіти. 


\section{СПИСОК ВИКОРИСТАНОЇ ЛІТЕРАТУРИ}

Про освіту: Закон України від 05.09.2017 р. № 2145-VIII. URL: http://search.ligazakon.ua/l doc2.nsf/ link1/T172145.html (дата звернення: 23.01.2021).

Про затвердження Порядку проведення інституційного аудиту закладів загальної середньої освіти: наказ МОН України від 09.01.2019 р. № 17. URL: https:// zakon.rada.gov.ua/laws/show/z0250-19\#Text (дата звернення: 23.01.2021).

Методичні рекомендації 3 питань формування внутрішньої системи забезпечення якості освіти у закладах дошкільної освіти: наказ ДСЯОУ від 30.11.2020 p. № 01-11/71. URL: https://osvita.ua/legislation/doshkilnaosvita/77870/ (дата звернення: 22.01.2021).

Планування роботи в дошкільних навчальних закладах: лист МОН України від 03.07.2009 p. № 1/9-455. URL: https://bit.ly/3ppA0yB (дата звернення: 22.01.2021).

Про затвердження Базового компонента дошкільної освіти (Державного стандарту дошкільної освіти). Нова редакція: наказ МОН України від 12.01.2021 p. № 33. URL : https://bit.ly/3iVt5Lc (дата звернення: 22.01.2021).

Інструктивно-методичні рекомендації «Щодо організації діяльності закладів дошкільної освіти у 2020/2021 навчальному році»: лист МОН України від 30.07.2020 p. № 1/9-411. URL: https://bit.ly/2YwLrIN (дата звернення: 22.01.2021).

Енциклопедія освіти. (2008) / Акад. пед. наук України; гол. ред. В. Г. Кремень. Київ: Юрінком Інтер. $1040 \mathrm{c}$.

Богуш, А. М. (2015). Підготовка дітей до школи у вимірі дошкільної зрілості. Збірник наукових праиь Херсонського державного університету. Серія «Педагогіні науки». Вип. 67. С. 158-163.

\section{REFERENCES}

Pro osvitu: Zakon Ukrainy vid 05.09.2017 r. № 2145VIII [Law of Ukraine "On Education»]. URL: http:// search.ligazakon.ua/1_doc2.nsf/link1/T172145.html (data zvernennia: 23.01.2021). [in Ukrainian].

Pro zatverdzhennia Poriadku provedennia instytutsiinoho audytu zakladiv zahalnoi serednoi osvity: nakaz MON Ukrainy vid 09.01.2019 r. № 17 [Approval of the Procedure for conducting an institutional audit of general secondary education institutions: order of the Ministry of Education and Science of Ukraine]. URL: https://zakon. rada.gov.ua/laws/show/z0250-19\#Text (data zvernennia: 23.01.2021). [in Ukrainian].

Metodychni rekomendatsii z pytan formuvannia vnutrishnoi systemy zabezpechennia yakosti osvity u zakladakh doshkilnoi osvity: nakaz DSIaOU vid 30.11.2020 r. № 01-11/71 [Methodical recommendations on the formation of the internal system of quality assurance of education in preschool institutions: the order of State Service for the Quality of Education of Ukraine]. URL: https://osvita. ua/legislation/doshkilna-osvita/77870/ (data zvernennia: 22.01.2021). [in Ukrainian].

Planuvannia roboty $\mathrm{v}$ doshkilnykh navchalnykh zakladakh: lyst MON Ukrainy vid 03.07.2009 r. № 1/9-455 [Planning of work in preschool educational institutions: letter of the Ministry of Education and Science of Ukraine]. URL: https://bit.ly/3ppA0yB (data zvernennia: 22.01.2021). [in Ukrainian].

Pro zatverdzhennia Bazovoho komponenta doshkilnoi osvity (Derzhavnoho standartu doshkilnoi osvity). Nova redaktsiia: nakaz MON Ukrainy vid 12.01.2021 r. № 33 [About the statement of the Basic component of preschool education (the State standard of preschool education). New edition: order of the Ministry of Education and Science of Ukraine]. URL: https://bit. ly/3iVt5Lc (data zvernennia: 22.01.2021). [in Ukrainian].

Instruktyvno-metodychni rekomendatsii «Shchodo orhanizatsii diialnosti zakladiv doshkilnoi osvity u 2020/2021 navchalnomu rotsi»: lyst MON Ukrainy vid 30.07.2020 r. № 1/9-411 [Instructional and methodical recommendations «On the organization of preschool education in the 2020/2021 school year»: letter of the Ministry of Education and Science of Ukraine]. URL: https://bit.ly/2YwLrIN (data zvernennia: 22.01.2021). [in Ukrainian].

Entsyklopediia osvity [Encyclopedia of Education]. (2008) / Akad. ped. nauk Ukrainy; hol. red. V. H. Kremen. Kyiv: Yurinkom Inter. 1040 s. [in Ukrainian].

Bohush A. M. (2015). Pidhotovka ditei do shkoly u vymiri doshkilnoi zrilosti [Preparing children for school in the dimension of preschool maturity]. Zbirnyk naukovykh prats Khersonskoho derzhavnoho universytetu. Seriia "Pedahohini nauky». Vyp. 67. S. 158-163. [in Ukrainian].

Дата надходження до редакиії: 03.02.2021 p. 